\title{
Long-Term Outcomes Following Thermal Ablation of Benign Thyroid Nodules as an Alternative to Surgery: The Importance of Controlling Regrowth
}

\author{
Jung Suk Sim ${ }^{1}$, Jung Hwan Baek² \\ ${ }^{1}$ Department of Radiology, Withsim Clinic, Seongnam; ${ }^{2}$ Department of Radiology and the Research Institute of Radiology, Asan \\ Medical Center, University of Ulsan College of Medicine, Seoul, Korea
}

Thermal ablation (TA) procedures, such as radiofrequency ablation and laser ablation, are used for the treatment of benign thyroid nodules. Short-term studies ( $<2$ years) have demonstrated that TA is an effective and safe procedure to improve cosmetic or symptomatic problems. However, studies including a longer follow-up period show that treated thyroid nodules can increase in size after 2 to 3 years. Several studies suggest that this results from regrowth at the undertreated nodule margins. Here, we review current data on regrowth after TA and describe factors related to it and possible approaches to prevent it.

Keywords: Thyroid nodule; Ablation

\section{INTRODUCTION}

Thermal ablation (TA) procedures, such as radiofrequency ablation (RFA) and laser ablation (LA), are used to treat benign thyroid nodules [1,2]. Short-term studies ( $<1$ to 2 years) showed that TA is effective and safe for the treatment of cosmetic or symptomatic problems, resulting in a reduction in nodule volume of $50 \%$ to $80 \%$ [2]. Some authors suggest that the primary purpose of TA is to improve pressure symptoms rather than to provide complete ablation $[3,4]$. When LA and RFA were first introduced in the 2000s, this paradigm formed the main strategy for patients who were either unable or unwilling to undergo surgery $[5,6]$. As an alternative to surgery, early TA was aimed at relatively short-term palliation due to the poor general condition of the patient when the initial volume of the nodule was rela-

Received: 5 May 2019, Revised: 15 May 2019, Accepted: 22 May 2019

Corresponding author: Jung Hwan Baek

Department of Radiology and the Research Institute of Radiology, Asan Medical Center, University of Ulsan College of Medicine, 88 Olympic-ro 43-gil, Songpa-gu, Seoul 05505, Korea

Tel: +82-2-3010-4348, Fax: +82-2-476-0090, E-mail: radbaek@naver.com tively small. The goal of TA at that time was to achieve an approximately $50 \%$ volume reduction, generally over a 1 -year period $[3,4]$. However, several studies with longer follow-up periods subsequently showed a tendency for the treated thyroid nodules to increase in size after 2 to 3 years [7-9]. With increasingly widespread awareness of the safety and effectiveness of TA, patients may choose minimally-invasive TA to avoid scarring in the highly-visible anterior neck area and to reduce the risk of hypothyroidism [10-13]. Therefore, to be considered as an alternative to surgery, TA procedures would need to be effective in the treatment of larger nodules and the effects of treatment should be sustainable for longer periods $[9,14,15]$. With this goal in mind, we have reviewed the issue of regrowth in studies of TA and we describe the factors related to nodule regrowth and strategies to manage this problem.

Copyright $\odot 2019$ Korean Endocrine Society

This is an Open Access article distributed under the terms of the Creative Commons Attribution Non-Commercial License (http://creativecommons.org/ licenses/by-nc/4.0/) which permits unrestricted non-commercial use, distribution, and reproduction in any medium, provided the original work is properly cited. 


\section{DEFINITION AND FACTORS RELATED TO REGROWTH}

To date, several TA studies have reported unsatisfactory results related to regrowth and/or the need for further treatment, such as additional TA or surgery (Table 1) [7,9,15-21]. In their 2009 study of RFA for the treatment of autonomous nodules, Baek et al. [22] reported observations of regrowth of the untreated peripheral regions, and later described this as 'marginal regrowth' [8]. However, similar terms, such as regrowth, marginal regrowth, and recurrence are used under different definitions and criteria. Some researchers prefer to use the term 'recurrence' while others prefer to use 'regrowth' under virtually the same meaning $[23,24]$. Many authors have defined regrowth as an increase in nodule volume $>50 \%$ over the previously recorded volume $[7,9,25]$. Others define regrowth as a post-treatment volume greater than the initial nodule volume [16]. Papini et al. [17] used the term 'partial regrowth' when the volume was $>20 \%$ larger than the volume at 1 year after treatment. Authors have also applied the term regrowth to indicate an increase in nodule volume, but without providing quantitative criteria [26].

For this manuscript, we defined nodule regrowth as an increase of $>50 \%$ over the smallest previously recorded volume. Marginal regrowth is used to describe the phenomenon of re-

Table 1. Studies Referring to Nodule Regrowth or a Requirement for Multiple Sessions of Thermal Ablation

\begin{tabular}{|c|c|c|c|c|c|c|c|}
\hline Study & $\begin{array}{c}\text { No. of } \\
\text { nodules }\end{array}$ & Modalities & $\begin{array}{l}\text { Initial } \\
\text { volume, } \\
\mathrm{mL}\end{array}$ & $\begin{array}{l}\text { FU } \\
\text { period }\end{array}$ & $\begin{array}{l}\text { No. of } \\
\text { sessions }\end{array}$ & $\begin{array}{l}\text { VRR, } \\
\%\end{array}$ & Description on the regrowth or the need of further treatment \\
\hline Spiezia et al. (2009) [20] & 94 & RFA & 24.5 & $24 \mathrm{mo}$ & $1-3$ & 79.4 & $\begin{array}{l}34 \% \text { of patients required more than one sessions of RFA; total } \\
\text { no-dule volume before RFA treatment was }>20 \mathrm{~mL} \text {. }\end{array}$ \\
\hline Valcavi et al. (2010) [16] & 122 & LA & 23.1 & $3 \mathrm{yr}$ & 1 & 48 & $\begin{array}{l}\text { A subgroup of } 11 \text { patients }(9.0 \%) \text { experienced regrowth of the } \\
\text { nodule above the initial value. }\end{array}$ \\
\hline Dossing et al. (2011) [18] & 78 & LA & 8.2 & $69 \mathrm{mo}$ & NA & 51 & $\begin{array}{l}35 \% \text { Underwent thyroid surgery because of unsatisfactory results } \\
\text { after ILP therapy. }\end{array}$ \\
\hline $\begin{array}{l}\text { Gambelunghe et al. (2013) } \\
\text { [19] }\end{array}$ & 20 & LA & 14 & $3 \mathrm{yr}$ & 1 & 57 & $\begin{array}{l}\text { The delivery of lower energy inevitably resulted in nodule re- } \\
\text { growth and, therefore, a second treatment. At the 3-year follow- } \\
\text { up timepoint, the nodules tended to grow to a greater volume } \\
\text { than that observed prior to treatment. }\end{array}$ \\
\hline Lim et al. (2013) [7] & 126 & RFA & 9.8 & 49.4 mo & 2.2 & 93.5 & $\begin{array}{l}\text { The overall recurrence rate was } 5.6 \% \text {. All recurrent nodules } \\
\text { showed regrowth of the undertreated peripheral region. }\end{array}$ \\
\hline Papini et al. (2014) [17] & 101 & LA & 12 & $3 \mathrm{yr}$ & & 58 & $\begin{array}{l}\text { At the } 3 \text {-year follow-up timepoint, } 5 \% \text { of patients presented with } \\
\text { partial regrowth (defined as a } 20 \% \text { increase vs. the } 1 \text {-year post- } \\
\text { treatment volume). }\end{array}$ \\
\hline Sung et al. (2015) [21] & $\begin{array}{l}44 \text { Hot } \\
\text { nodules }\end{array}$ & RFA & 18.5 & $19.9 \mathrm{mo}$ & 1.8 & 8.17 & $\begin{array}{l}\text { Two of the five patients were not able to stop their medication, } \\
\text { although the amount of medication could be decreased after } \\
\text { ablation. }\end{array}$ \\
\hline Sim et al. (2017) [9] & 54 & RFA & 14.0 & $39.4 \mathrm{mo}$ & 1 & 77 & $\begin{array}{l}\text { Regrowth occurred in } 24.1 \% \text { of nodules; the mean timing of } \\
\text { regrowth was } 39.9 \text { months. Regrowth began at } 12 \text { months and } \\
\text { tended to be prominent at } 2-4 \text { years post-treatment. A secondary } \\
\text { peak of regrowth appeared after } 5 \text { years. This delayed regrowth } \\
\text { suggests that long-term stabilized nodules can show regrowth in } \\
\text { a slowly growing, marginal, incompletely treated area and } \\
\text { additional ablation is necessary to prevent long-term regrowth. }\end{array}$ \\
\hline $\begin{array}{l}\text { Gambelunghe et al. (2018) } \\
\text { [15] }\end{array}$ & 82 & LA & 12 & $3 \mathrm{yr}$ & 1 & 53 & $\begin{array}{l}\text { Repeated sessions are necessary in large toxic thyroid nodules, } \\
\text { the major limitation is the risk of incomplete and insufficient } \\
\text { ablation of the external border of the hyperfunctioning lesion, } \\
\text { followed by regrowth and relapse of hyperthyroidism at long- } \\
\text { term follow-up. }\end{array}$ \\
\hline
\end{tabular}

FU, follow-up; VRR, volume reduction ratio; RFA, radiofrequency ablation; LA, laser ablation; NA, not available; ILP, interstitial laser photocoagulation. 
growth occurring from the undertreated peripheral areas. Most cases of regrowth occur as a result of marginal regrowth.

If the margin of the nodule is insufficiently ablated, regrowth can occur sometime after TA; one 4-year follow-up study reported that solid nodules tended to regrow after 2 years [7]. A follow-up study of up to 7 years after single-session ablation reported that regrowth occurs in $24.1 \%$ of cases, at an average of 39 months after RFA [9].

The most common risk factor for marginal regrowth is a large initial nodule volume [18,27]. In a study by Wang et al. [24], 16 of 110 patients experienced recurrence 12 months after microwave ablation and the mean initial volume of the nodules showing recurrence was significantly larger than the non-recurring nodules. The ablation technique is considered to be another important factor associated with regrowth. Lim et al. [7] described regrowth occurring from the incompletely-treated peripheral regions and concluded that controlling the peripheral margin of the nodule with a moving-shot technique is important to prevent marginal regrowth. The anatomical location of the nodule should also be considered. Nodules that are too close to critical structures, such as the recurrent laryngeal nerve or carotid sheath, are more likely to undergo regrowth from the viable tissue remaining after incomplete ablation [28,29].

\section{ADEQUATE APPLICATION OF MULTIPLE SESSION ABLATION}

According to the 2017 thyroid RFA guidelines developed by the Korean Society of Thyroid Radiology, multiple-session ablation may be required for large nodules [1], and this view has been supported by other authors [19,30]. However, there is no consensus about the specific indication or appropriate timing for multiple ablations [2].

Cervelli et al. [31] noted that in nodules with a post-treatment volume $>9 \mathrm{~mL}$ and a residual viable tissue volume $>4 \mathrm{~mL}$, additional ablation should be performed 1 year after treatment when the ablated tissue has become sufficiently fibrotic. They suggested that during the 1-year post-treatment period, the ablated tissues, which are mainly located at the center of the nodule, are absorbed and the marginal residual tissue is at a sufficient thickness to be treated by additional ablation [31]. Huh et al. [30] compared the outcomes between patients undergoing single-session RFA and those receiving additional ablation 1 month later, showing no significant difference in the 1-year follow-up results between the two groups. The lack of effect in Huh's study [30] may be due to the relatively small size of treat- ed nodules and short interval between the first RFA and the additional ablation. At 1-month post-treatment, residual marginal tissue would be thin and additional ablation may, therefore, not be effective.

Recent studies have focused on the need for earlier identification of nodule regrowth. Sim et al. [9] proposed a method of tracking the volume of the nodule after RFA by dividing it into the total volume $(\mathrm{Vt})$, ablated volume $(\mathrm{Va})$, and viable volume $(\mathrm{Vv})$. Because the reduction in Va occurs rapidly in the initial stages after RFA, growth of the Vv may be masked and Vt may be misinterpreted as decreasing. Therefore, measuring the $\mathrm{Vv}$ separately is advantageous for identifying earlier signs of regrowth (Fig. 1) [9]. While very few studies have provided evidence for the appropriate timing for additional ablation, assessment of the $\mathrm{Va}, \mathrm{Vv}$, and $\mathrm{Vt}$ during follow-up can provide a useful indication. When the $V_{v}$ begins to increase, it is time to consider additional ablation; when the $\mathrm{Vv}$ increases and the $\mathrm{Va}$ is small, as shown in Fig. 1C, it is an appropriate point to perform additional RFA. However, even if the Vv is increasing, if the Va is rapidly decreasing, it is advisable to delay additional ablation, and ultrasonography follow-up at 1- to 3-month intervals should be conducted. When the rate of increasing $\mathrm{Vv}$ exceeds the rate of decreasing Va, additional ablation should be considered.

Other efforts have been made to identify the remaining viable portion of nodules through contrast-enhanced ultrasonography (CEUS). CEUS can be used to detect the undertreated area immediately or shortly (1 month) after TA, enabling prompt delivery of additional treatment [27,32-34]. This method is one approach to increasing the ablation ratio, as described in the section below [34].

\section{ADVANCES IN TECHNIQUES FOR REDUCING MARGINAL REGROWTH}

When the volume of a nodule is too large to completely ablate it in single session of TA, the initial session aims to ablate the nodule tissue as much as possible. The extent of ablation within the Vt, i.e., the ablation ratio, has a significant impact on future volume reduction. Recently, Sim et al. [35] used the term initial ablation ratio (IAR). Ablation ratio is a ratio of the volume of ablated tissue to the total nodule volume. IAR is an ablation ratio calculated shortly after TA. The meaning of IAR is how much did an operator ablate the nodule tissue with TA. Thus, IAR is a quantitative index representing the performance of a TA procedure, in other words, how well an operator did the TA. In their study, they found that the IAR and the volume reduction 

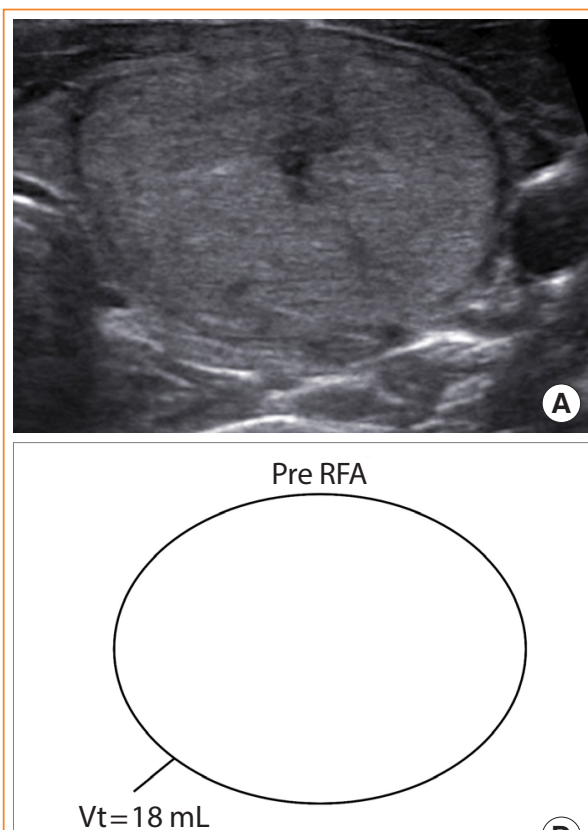

$\mathrm{Vt}=18 \mathrm{~mL}$

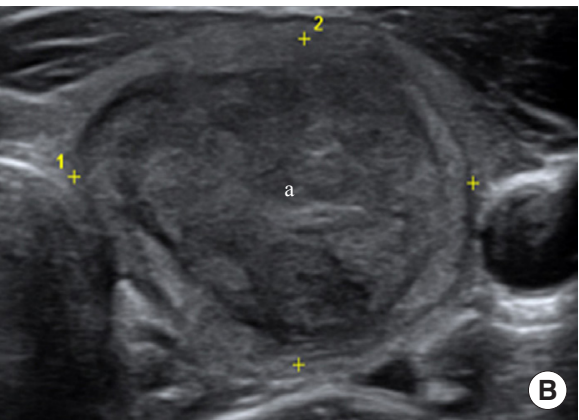

B

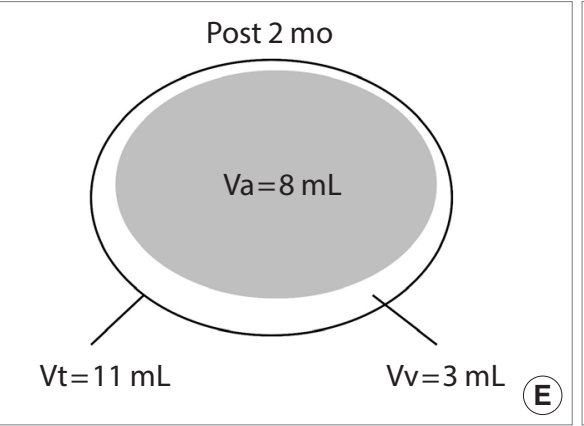

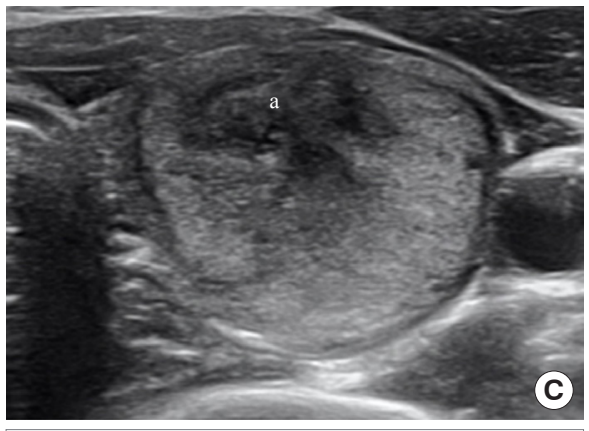

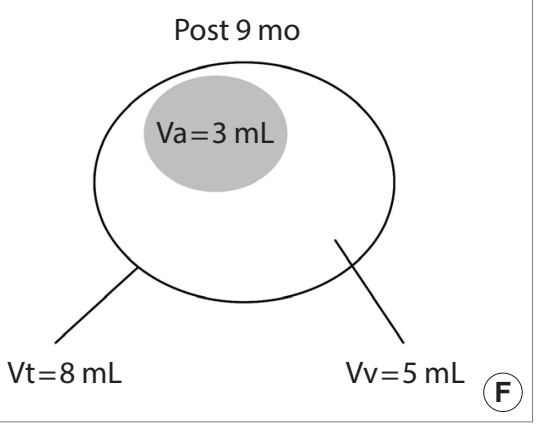

Fig. 1. Ultrasonography of a thyroid nodule: (A) pre-radiofrequency ablation (RFA), (B) 2 months post-RFA, and (C) 9 months post-RFA. (D-F) Diagrams indicate the total volume (Vt), ablated volume (Va), and viable volume (Vv) at these timepoints. Although Vt decreases over time, $\mathrm{Vv}$ increased by $2 \mathrm{~mL}$ between months 2 and 9, indicating that growth of the residual viable nodule tissue had already begun. In this case, additional RFA was performed 1 month after obtaining the image in C. ${ }^{\text {a }}$ The centrally-located hypoechoic area of ablated tissue is indicated.
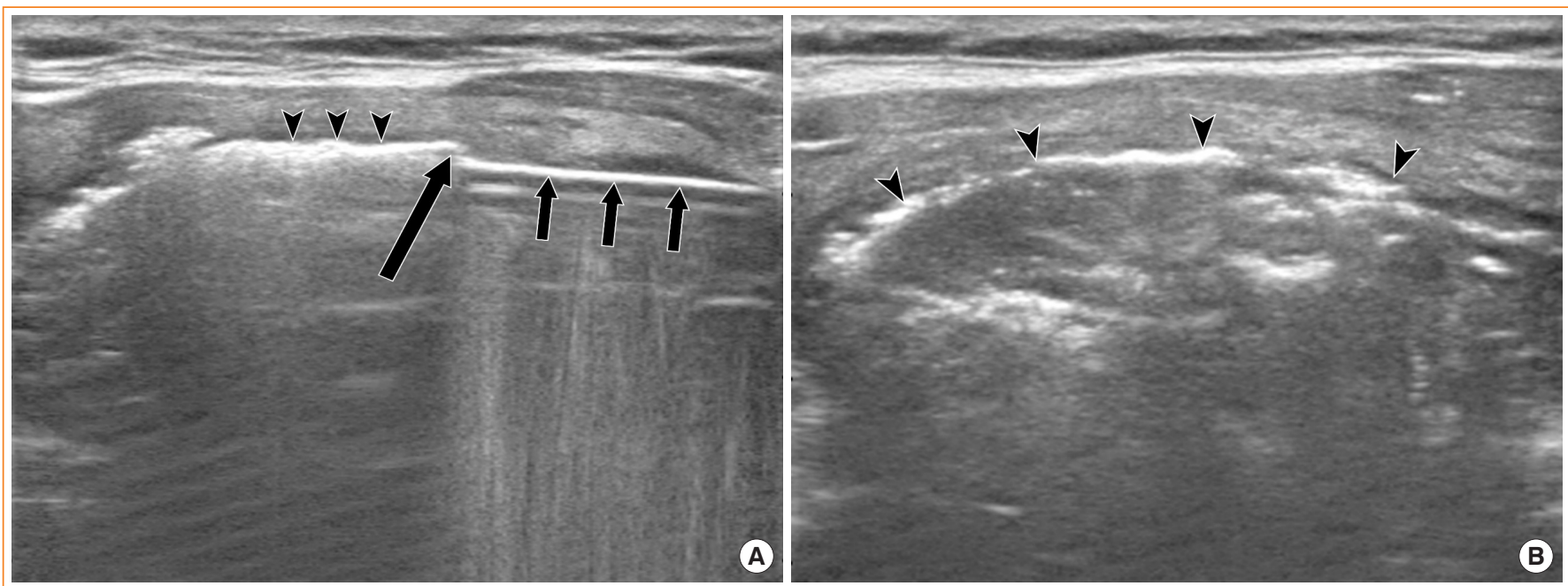

Fig. 2. (A) An electrode (short arrows) directly ablates the perinodular vein (arrow). Air bubbles are seen inside the venous lumen (arrowheads). (B) After completing venous ablation, compact filling of hot air bubbles is observed (arrowheads).

ratio (VRR) were positively correlated, so that a high VRR was achieved when IAR was high, and $50 \%$ VRR could be expected when $\geq 70 \%$ IAR was achieved [35]. Gambelunghe et al. [19] suggested that complete ablation (or a very high percentage of ablation) is essential to achieve a marked reduction in the thy- roid nodule. In a high intensity focused ultrasound study of mild Graves' disease, Lang et al. [36] hypothesized that the ablation volume ratio may be a factor in disease relapse.

By contrast, once the volume of the nodule has reduced, it is important to minimize the amount of residual tissue in order to 
limit regrowth. To achieve this, different techniques and devices are required. Vascular ablation techniques were recently introduced by Park et al. [37], namely, the artery-first ablation technique and the marginal venous ablation technique. The arteryfirst technique ablates the tumor-feeding artery first to minimize the heat-sink effect and to reduce the possibility of hemorrhage during the procedure. The draining vein, which is primarily located in the margin of the tumor, interferes with the complete ablation of the margin due to the heat-sink effect. Ablation of these veins can lead to complete ablation of the nodule margin. After puncturing a portion of the vein with the electrode, ablation is initiated when air bubbles are formed and flow into the veins. While this occurs, the veins are filled with hot air bubbles and venous flow eventually ceases, retaining white air bubbles in the lumen of the marginal veins. The marginal venous ablation technique is particularly helpful to prevent marginal regrowth (Fig. 2) [37].

When the nodule tissue is close to a critical structure, it is technically difficult to ablate the tissue completely. This situation is common on the medial side, near the recurrent laryngeal nerve, around the carotid sheath where the vagus nerve and sympathetic ganglions are located, and on the posterior side, where anatomical variation occasionally occurs [29]. Therefore, it is helpful to artificially create a margin of safety at these locations. The hydrodissection technique is one method used for this purpose and involves the injection of a fluid, such as 5\% dextrose [1]. After the needle is inserted between the nodule and the critical structures, ablation is performed while fluid is continuously injected, or immediately after injecting fluid to form safety margin of $\geq 5 \mathrm{~mm}$. Using this method, effective ablation can be achieved, thereby minimizing the residual margin of viable tissue [32,37].

\section{CONCLUSIONS}

With greater knowledge of the factors associated with nodule regrowth and strategies to manage this issue, it is possible to improve the clinical outcome of TA by minimizing marginal regrowth. In so doing, it is possible that the outcomes of TA may be comparable to that of surgery.

\section{CONFLICTS OF INTEREST}

This study received no funding in the form of grants. Jung Hwan Baek's financial activities are not related to the present article (patent holder of a unidirectional ablation electrode); he has been a consultant to two radiofrequency companies, STARmed and RF Medical, since 2017.

\section{ORCID}

Jung Suk Sim https://orcid.org/0000-0001-6803-3544

Jung Hwan Baek https://orcid.org/0000-0003-0480-4754

\section{REFERENCES}

1. Kim JH, Baek JH, Lim HK, Ahn HS, Baek SM, Choi YJ, et al. 2017 Thyroid radiofrequency ablation guideline: Korean Society of Thyroid Radiology. Korean J Radiol 2018;19: 632-55.

2. Cesareo R, Palermo A, Pasqualini V, Cianni R, Gaspa G, Manfrini S, et al. Radiofrequency ablation for the management of thyroid nodules: a critical appraisal of the literature. Clin Endocrinol (Oxf) 2017;87:639-48.

3. Papini E, Guglielmi R, Bizzarri G, Graziano F, Bianchini A, Brufani $\mathrm{C}$, et al. Treatment of benign cold thyroid nodules: a randomized clinical trial of percutaneous laser ablation versus levothyroxine therapy or follow-up. Thyroid 2007;17: 229-35.

4. Deandrea M, Limone P, Basso E, Mormile A, Ragazzoni F, Gamarra E, et al. US-guided percutaneous radiofrequency thermal ablation for the treatment of solid benign hyperfunctioning or compressive thyroid nodules. Ultrasound Med Biol 2008;34:784-91.

5. Pacella CM, Bizzarri G, Guglielmi R, Anelli V, Bianchini A, Crescenzi A, et al. Thyroid tissue: US-guided percutaneous interstitial laser ablation-a feasibility study. Radiology 2000; 217:673-7.

6. Jeong WK, Baek JH, Rhim H, Kim YS, Kwak MS, Jeong HJ, et al. Radiofrequency ablation of benign thyroid nodules: safety and imaging follow-up in 236 patients. Eur Radiol 2008; 18:1244-50.

7. Lim HK, Lee JH, Ha EJ, Sung JY, Kim JK, Baek JH. Radiofrequency ablation of benign non-functioning thyroid nodules: 4-year follow-up results for 111 patients. Eur Radiol 2013; 23:1044-9.

8. Baek JH, Lee JH, Valcavi R, Pacella CM, Rhim H, Na DG. Thermal ablation for benign thyroid nodules: radiofrequency and laser. Korean J Radiol 2011;12:525-40.

9. Sim JS, Baek JH, Lee J, Cho W, Jung SI. Radiofrequency ablation of benign thyroid nodules: depicting early sign of regrowth by calculating vital volume. Int J Hyperthermia 2017; 
33:905-10.

10. Bernardi S, Dobrinja C, Fabris B, Bazzocchi G, Sabato N, Ulcigrai $\mathrm{V}$, et al. Radiofrequency ablation compared to surgery for the treatment of benign thyroid nodules. Int J Endocrinol 2014;2014:934595.

11. Radzina M, Cantisani V, Rauda M, Nielsen MB, Ewertsen C, D'Ambrosio F, et al. Update on the role of ultrasound guided radiofrequency ablation for thyroid nodule treatment. Int J Surg 2017;41 Suppl 1:S82-93.

12. Mauri G, Pacella CM, Papini E, Sconfienza LM, Solbiati L. Proceedings of the first Italian conference on thyroid minimally invasive treatments and foundation of the Italian research group for thyroid minimally invasive procedures. Int J Hyperthermia 2018;34:603-5.

13. Ha EJ, Baek JH, Kim KW, Pyo J, Lee JH, Baek SH, et al. Comparative efficacy of radiofrequency and laser ablation for the treatment of benign thyroid nodules: systematic review including traditional pooling and bayesian network meta-analysis. J Clin Endocrinol Metab 2015;100:1903-11.

14. Park HS, Baek JH, Choi YJ, Lee JH. Innovative techniques for image-guided ablation of benign thyroid nodules: combined ethanol and radiofrequency ablation. Korean J Radiol 2017;18:461-9.

15. Gambelunghe G, Stefanetti E, Colella R, Monacelli M, Avenia N, De Feo P. A single session of laser ablation for toxic thyroid nodules: three-year follow-up results. Int J Hyperthermia 2018;34:631-5.

16. Valcavi R, Riganti F, Bertani A, Formisano D, Pacella CM. Percutaneous laser ablation of cold benign thyroid nodules: a 3-year follow-up study in 122 patients. Thyroid 2010;20: 1253-61.

17. Papini E, Rago T, Gambelunghe G, Valcavi R, Bizzarri G, Vitti P, et al. Long-term efficacy of ultrasound-guided laser ablation for benign solid thyroid nodules. Results of a threeyear multicenter prospective randomized trial. J Clin Endocrinol Metab 2014;99:3653-9.

18. Dossing H, Bennedbaek FN, Hegedus L. Long-term outcome following interstitial laser photocoagulation of benign cold thyroid nodules. Eur J Endocrinol 2011;165:123-8.

19. Gambelunghe G, Fede R, Bini V, Monacelli M, Avenia N, D'Ajello M, et al. Ultrasound-guided interstitial laser ablation for thyroid nodules is effective only at high total amounts of energy: results from a three-year pilot study. Surg Innov 2013; 20:345-50.

20. Spiezia S, Garberoglio R, Milone F, Ramundo V, Caiazzo C, Assanti AP, et al. Thyroid nodules and related symptoms are stably controlled two years after radiofrequency thermal ablation. Thyroid 2009;19:219-25.

21. Sung JY, Baek JH, Jung SL, Kim JH, Kim KS, Lee D, et al. Radiofrequency ablation for autonomously functioning thyroid nodules: a multicenter study. Thyroid 2015;25:112-7.

22. Baek JH, Moon WJ, Kim YS, Lee JH, Lee D. Radiofrequency ablation for the treatment of autonomously functioning thyroid nodules. World J Surg 2009;33:1971-7.

23. Suh CH, Baek JH, Ha EJ, Choi YJ, Lee JH, Kim JK, et al. Ethanol ablation of predominantly cystic thyroid nodules: evaluation of recurrence rate and factors related to recurrence. Clin Radiol 2015;70:42-7.

24. Wang B, Han ZY, Yu J, Cheng Z, Liu F, Yu XL, et al. Factors related to recurrence of the benign non-functioning thyroid nodules after percutaneous microwave ablation. Int $\mathrm{J}$ Hyperthermia 2017;33:459-64.

25. Haugen BR, Alexander EK, Bible KC, Doherty GM, Mandel SJ, Nikiforov YE, et al. 2015 American Thyroid Association management guidelines for adult patients with thyroid nodules and differentiated thyroid cancer: the American Thyroid Association guidelines task force on thyroid nodules and differentiated thyroid cancer. Thyroid 2016;26:1-133.

26. Piana S, Riganti F, Froio E, Andrioli M, Pacella CM, Valcavi R. Pathological findings of thyroid nodules after percutaneous laser ablation: a series of 22 cases with cyto-histological correlation. Endocr Pathol 2012;23:94-100.

27. Zhao CK, Xu HX, Lu F, Sun LP, He YP, Guo LH, et al. Factors associated with initial incomplete ablation for benign thyroid nodules after radiofrequency ablation: first results of CEUS evaluation. Clin Hemorheol Microcirc 2017;65:393405.

28. Baek JH, Lee JH, Sung JY, Bae J, Kim KT, Sim J, et al. Complications encountered in the treatment of benign thyroid nodules with US-guided radiofrequency ablation: a multicenter study. Radiology 2012;262:335-42.

29. Kim C, Lee JH, Choi YJ, Kim WB, Sung TY, Baek JH. Complications encountered in ultrasonography-guided radiofrequency ablation of benign thyroid nodules and recurrent thyroid cancers. Eur Radiol 2017;27:3128-37.

30. Huh JY, Baek JH, Choi H, Kim JK, Lee JH. Symptomatic benign thyroid nodules: efficacy of additional radiofrequency ablation treatment session: prospective randomized study. Radiology 2012;263:909-16.

31. Cervelli R, Mazzeo S, De Napoli L, Boccuzzi A, PontilloContillo B, Materazzi G, et al. Radiofrequency ablation in the treatment of benign thyroid nodules: an efficient and 
safe alternative to surgery. J Vasc Interv Radiol 2017;28: 1400-8.

32. Yue WW, Wang SR, Lu F, Sun LP, Guo LH, Zhang YL, et al. Radiofrequency ablation vs. microwave ablation for patients with benign thyroid nodules: a propensity score matching study. Endocrine 2017;55:485-95.

33. Mauri G, Cova L, Monaco CG, Sconfienza LM, Corbetta S, Benedini S, et al. Benign thyroid nodules treatment using percutaneous laser ablation (PLA) and radiofrequency ablation (RFA). Int J Hyperthermia 2017;33:295-9.

34. Li XL, Xu HX, Lu F, Yue WW, Sun LP, Bo XW, et al. Treatment efficacy and safety of ultrasound-guided percutaneous bipolar radiofrequency ablation for benign thyroid nodules. Br J Radiol 2016;89:20150858.

35. Sim JS, Baek JH, Cho W. Initial ablation ratio: quantitative value predicting the therapeutic success of thyroid radiofrequency ablation. Thyroid 2018;28:1443-9.

36. Lang BH, Woo YC, Wong IY, Chiu KW. Single-session high-intensity focused ultrasound treatment for persistent or relapsed Graves disease: preliminary experience in a prospective study. Radiology 2017;285:1011-22.

37. Park HS, Baek JH, Park AW, Chung SR, Choi YJ, Lee JH. Thyroid radiofrequency ablation: updates on innovative devices and techniques. Korean J Radiol 2017;18:615-23. 